\title{
Risk Factors for Non-communicable Diseases in Vietnam: A Focus on Pesticides
}

\author{
Hoang V. Dang ${ }^{1 *}$, Luong T. Nguyen ${ }^{1}$, Ha T. Tran ${ }^{1}$, Huyen T. Nguyen ${ }^{1}$, Anh K. Dang ${ }^{1}$, \\ Viet D. Ly $^{1}$ and Chiara Frazzoli ${ }^{2}$ \\ ${ }^{1}$ Department of Biochemistry and Immunology, National Institute of Veterinary Research, Hanoi, Vietnam, ${ }^{2}$ Department of \\ Cardiovascular, Dysmetabolic and Aging-Associated Diseases, Istituto Superiore di Sanità, Rome, Italy
}

OPEN ACCESS

Edited by:

Mozammel Hoq

University of Dhaka, Bangladesh

Reviewed by:

Asaduzzaman,

University of Dhaka, Bangladesh

Munawar Sultana,

Department of Microbiology, University of Dhaka, Bangladesh

Christopher Jude Portier,

Private Researcher, Switzerland

*Correspondence:

Hoang V. Dang

dangnivr@yahoo.com

Specialty section:

This article was submitted to

Environmental Health,

a section of the journal

Frontiers in Environmental Science

Received: 30 August 2016

Accepted: 29 August 2017

Published: 12 September 2017

Citation:

Dang HV, Nguyen LT, Tran HT, Nguyen HT, Dang AK, Ly VD and Frazzoli C (2017) Risk Factors for

Non-communicable Diseases in Vietnam: A Focus on Pesticides.

Front. Environ. Sci. 5:58

doi: 10.3389/fenvs.2017.00058
Agent Orange, which was used in southern Vietnam, is confirmed the main source of dioxin exposure in Vietnam. Since early 1990s, agriculture of Vietnam has attained advances under intensive cultivation. Both production and yields per crop have increased significantly at the farm level, but the quantity of pesticides used in agriculture also increased in the absence of regulations and good practices. Illegal business of pesticides with false labels, as well as marketing of expired or poor quality products in stores without license are popular in Vietnam. Misuse and improper use in agriculture in Vietnam has led to a variety of problems, such as environmental pollution (including food producing animals) and adverse health impact on animals and humans. Open dumpsites worsen the general scenario. Similar to the environmental exposure, human exposure to DDT in Vietnam was ranked among the highest worldwide, with recognized effects. Exposed communities have to face birth defects, health disorders and non-communicable diseases (NCDs), from metabolic syndrome, asthma, infertility and other reproductive disorders through to diabetes, obesity, cardiovascular and neurodegenerative diseases, and cancer. A common feature of many chronic disorders and NCDs is metabolic disruption: environmental chemical factors disturb cellular homeostasis, thus affecting the ability of the body to restore a functional internal environment. Among these, endocrine disrupting pesticides can interfere with the action of hormones including metabolic hormones, and are likely to represent the main concern for developmentally-induced NCDs. Since pesticides are often persistent and bio-accumulate in the food chain through the living environment of food-producing organisms, this paper discusses relevant aspects of risk assessment, risk communication and risk management.

Keywords: Vietnam, pesticides, one health, exposure, metabolic syndrome, risk analysis

\section{EPIDEMIOLOGICAL TRANSITION IN VIETNAM}

The mortality rates of Vietnam is no high as other economically developing countries in Southeastern Asia, and mortality indicators suggest that Vietnam is experiencing an epidemiological transition (Huong, 2006; WHO, 2012, 2014). The WHO (World Health Organization) country profile reports the non-communicable diseases (NCDs) accounting for 75\% of all deaths in Vietnam (WHO, 2012). Changes in Vietnamese population follow two main drivers (Hoa et al., 2012): 
I Geographic distribution and social characteristics due to socioeconomic development and rapid urbanization.

II Demography, because of declining birth rate, longer life span and the transition in causes of death.

In 2002 the Vietnam's Prime Minister ratified with Decision 77/2002/QD-TTg for the first time that Vietnam would have a National Target Program for the prevention and control of NCDs. Besides other factors like genetics, changes in diet, physical exercise, stress, and aging, nutritional status and exposure to environmental dietary chemical factors, especially during development, affect health (Frazzoli et al., 2009). With regards to nutrition security, the Vietnamese Food based dietary guidelines (FBDGs) have been developed in Vietnam in 1995 and revised every 5 years (Hop et al., 2011).

As far as food safety is concerned, besides foods of vegetable origin, one should consider how with the development of semi-intensive rearing and the small food-processing industry, toxicants exposure transmittable by farm animal to humans may represent a new aspect of foodborne zoonoses (Frazzoli and Mantovani, 2010). Indeed, the development of an intensive rearing and processing industry introduces new and multiple risk factors, with the use of chemicals, as well as biological and pharmacological aids in animal productions, that call for risk assessment and management (Mantovani et al., 2015). In this scenario, the control programs of foods should develop around a food safety framework, based on new production chains, new exposure patterns, and disease scenarios. In fact, developmental exposure to environmental chemical factors may increase the risk of adverse pregnancy outcomes and impact on the programming of neurologic, metabolic, immune and reproductive functions, with major consequences on the risk of a variety of health disorders and NCDs in adult life, from metabolic syndrome, asthma, infertility and other reproductive disorders including puberty disturbances through to diabetes, obesity, cardiovascular and neurodegenerative diseases, and cancer (Costa et al., 2008; Van Der Mark et al., 2012; Mostafalou and Abdollahi, 2013; Tomar et al., 2013; Chevalier and Fénichel, 2014; Fucic and Mantovani, 2014; Jaacks and Staimez, 2015; Khalil et al., 2015). In this frame, according to the International Academy of Ecology and Environmental Sciences (Wenjun et al., 2011), the outbreak of cancer and other serious chronic diseases on a global scale (but especially in economically developing countries) is related to the rising environmental pollution with pesticides, accounting for $5-6 \%$. Chronic effects of particular relevance for pesticides are:

a) Neurobehavioral development (organophosphorus compounds, but also pyrethroids and neonicotinoids) and Parkinson's disease (European Food Safety Authority, 2016);

b) Cancer: older genotoxic poisons that are still used; emerging research reveals implication in childhood leukemia (European Food Safety Authority, 2016);

c) Infertility and other reproductive problems (EDC);

d) Thyroid, and in utero and childhood development; many pesticides are thyrostatic EDC (European Food Safety Authority, 2014); e) Link with metabolic syndrome, especially for EDC but also e.g., for substances that cause oxidative stress.

In this paper, we review the present situation of the risk of pesticides exposure in Vietnam (Figure 1) and reflect on possible actions for effective risk management.

\section{PESTICIDES IN VIETNAM}

Vietnam is known mainly as an agricultural country and one of the biggest rice exporting countries in the world (Thuong Hien, 2014). Agriculture in the north is concentrated in the lowland areas of the Red river delta and along the central coast southward. About $15 \%$ of the land in the north is arable, and $14 \%$ of it is already under intensive cultivation. The Mekong delta, one of the biggest rice-producing regions of the world, is also the dominant agricultural region of the South Vietnam.

Pesticides is a broad term that includes products such as biocides, which are intended for uses other than plant protection to control pests and disease carriers, such as insects, rats, and mice. Biocides are applied in several points of the food chain, from feeds to feed and food stores, farm animal barns, etc. Several chemicals used as pesticides, like organophosphorus or pyrethroid insecticides, may have a wide range of uses, either in agriculture to protect plants from diseases and infestations, as well as on farm animals, pets, buildings, gardens, and public places. However, the term "pesticides" is commonly understood as a synonym of plant protection drugs and include herbicides, fungicides, insecticides, acaricides, plant growth regulators, and repellents.

Pesticides have been frequently used in Vietnam in significant amounts to reduce crop losses and enhance agricultural (in particular rice) yields, with beneficial effect on food security. However, continuous misuse of pesticides in agriculture poses serious risks to both the ecosystem and human health. Until recently, the estimation of environmental burden of persistent organic pollutants (POPs), particularly organic chlorinated insecticides, in Vietnam has not been clear. The systematic inventory of toxic synthetic chemicals is lacking due to limited survey activities. In particular, studies on organochlorines and organophosphates have been performed while no information is available on recently used pesticides (particularly carbamates, pyrethroids, and triazoles). In general, a survey on agriculture (Berg, 2001) showed that $~ 50 \%$ of the pesticides used in Vietnam were insecticides and $25 \%$ were herbicides. In recent years, although the frequency of insecticide applications has been decreased, Vietnamese farmers have increased herbicide (paraquat is one of the most popular herbicides) or fungicide spraying due to increased demand of rice production. Particularly, a survey showed that more than $22 \%$ of the interviewed used pesticides three times for each crop (Berg, 2001). Besides pesticides use in rice cultivation, vegetables are also sprayed with pesticides by farmers in Vietnam, as an effective tool to maintain productivity and ensure the look of products.

The misuse of most pesticides and the lack of control by the authorities do pose a threat to human health and 


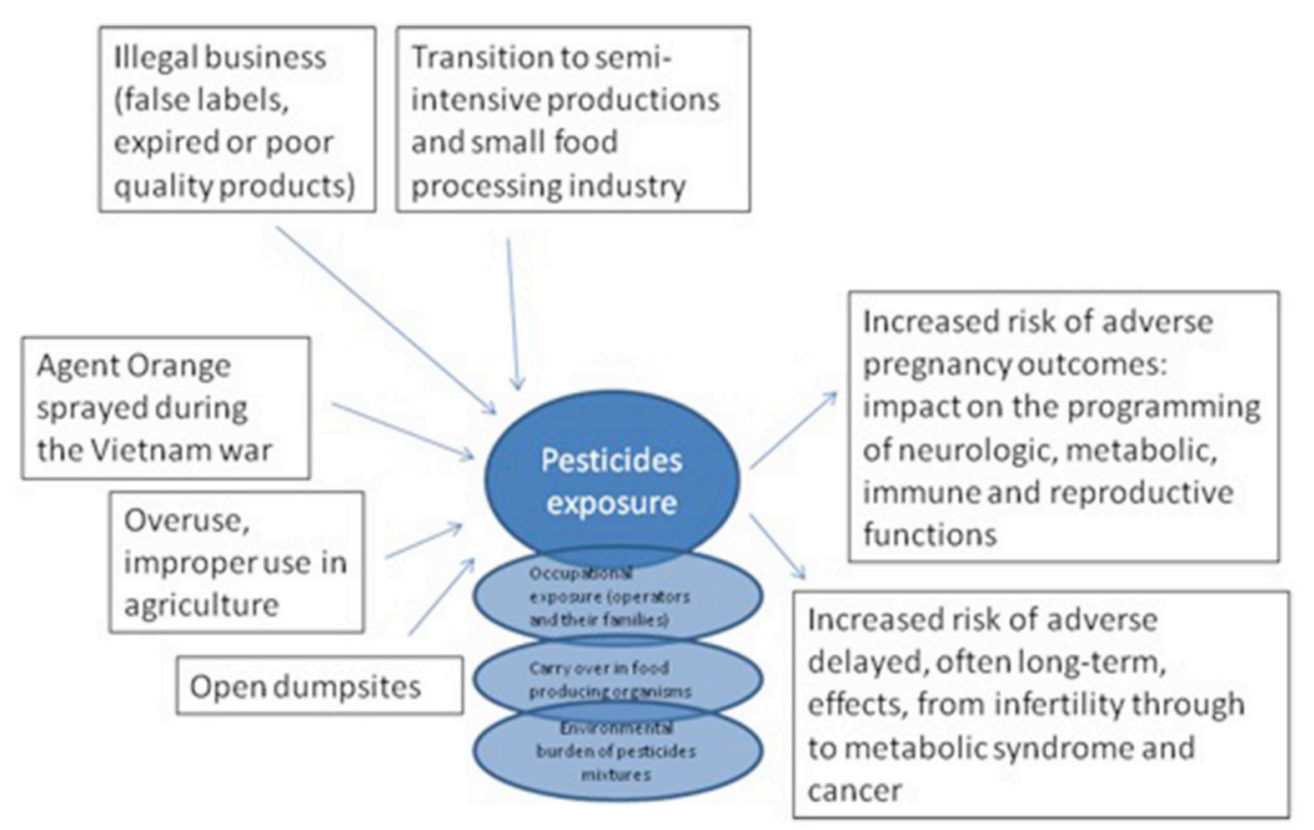

FIGURE 1 | Pesticides exposure sources and their long-term effect in Vietnam.

the environment. Overuse and improper use of pesticides in agricultural areas of Vietnam has led to a variety of problems, such as residue of pesticides in environmental matrices (soil, surrounding water and even sediments of river, and canal systems), and adverse health impact on animals and humans.

According to the Treatment Department of the Ministry of Health, there were over 3,000 cases of pesticide poisoning, nearly 3000 victims and over 100 people died in the first half of 2011 . According to Sarter et al. (2012), between 2002 and 2010, 10.4\% of poisoning outbreaks in Vietnam are due to chemicals and, in particular, pesticides' residues.

Besides substances intended for use in agriculture, the POPs exposure scenario is amplified by the exposure to hazardous environmental contaminants such as polychlorinated biphenyls (PCBs), whose environmental accumulation may be associated to oils imported from former Soviet Union, China, Romania and from electrical equipment like transformers (Frazzoli et al., 2010). Other possible sources of PCBs in Vietnam could be the weapons which were extensively used during the Indo-China war. The information about the usage of PCBs in Vietnam is still obscure, and it is necessary to get more data on pesticides residue in Vietnam.

An additional and remarkable pollution source of PCB, DDT in Vietnam and other Asia developing countries is open dumpsite systems (Minh et al., 2008).

Within the general population, Vietnamese farmers and their families and agricultural communities are the population groups generally more directly exposed to pesticides. Communities in rural areas have frequency of direct and indirect exposure to pesticides that is higher than communities living in the city, due to the activities in the paddy fields and other exposure pathways, such as contact with contaminated clothes at home. Rural women have to face various problems such as infectious outbreak or NCDs due to lack of safe water and exposure to the hazards of water sources polluted with fertilizers, pesticides, and so forth (Hussein, 2011).

\section{PESTICIDES MARKET}

In Vietnam, around 40,000 tons of plant protection drugs are produced by 97 chemical factories per year, and these amount of pesticides is distributed to 20,000 pesticide sales agents. Besides its national production, Vietnam annually imports about 100,000 tons of plant protection drugs and their materials with total importing value of 7 million USD (Hong, 2015). Of these, $80 \%$ (of which $45-47 \%$ are herbicides) are imported from China. Pesticides are $23 \%$ of total imported products. According to the MARD (Ministry of Agriculture and Rural Development), imported plant protection chemicals in 2005 was 20,000 tons, then the imported amount of pesticides in 2014 has increased up to 50,000 tons (Ha, 2015).

Vietnam has a long history of bulky presence of highly persistent pesticides; nearly 9,000 tons of dichlorodiphenyltrichloroethane (DDT) and hexachlorobenzene (HCB) were imported per year from former Soviet Union. In addition, it was counted that more than 24,000 tons of DDT was moved into Vietnam territory from 1955 to 1990 (Minh et al., 2008). According to Minh et al. (2007), during 1986-1990, 800 tons have been used.

From the early 1990s, the pesticide market has changed dramatically in Vietnam. The numbers of pesticides producing companies have grown quickly. New retailers have come into 
business and the market is overwhelmed by the annual increase of pesticide trade names. In particular, from 1999 to 2008 the number of active ingredients has almost doubled, while the number of trade names has increased 3.6 times. A report of the Ministry of industry and Trade shows 43 toxic chemicals in 286 commercial drug names (Ha, 2015). Highly toxic pesticides in Vietnam are abused and the control from authority agencies is lacking.

Quantity of category II pesticides increased from 18.4 to 40.6\% (Van Hoi et al., 2009, 2013). The increasing number of pesticide trade names of category II is associated with an increasing use of category II pesticides by farmers. Around 100 pesticide trade names corresponding to more than 50 different active ingredients, from more than 20 chemical groups, were used in surveyed areas (Toan et al., 2013). According to a survey among chemical groups used by respondent farmers in the Mekong river delta, the most commonly used pesticides were conazole fungicides followed by pyrethroid insecticides and biopesticides. Organophosphate pesticides, profenofos, and chlorpyrifos ethyl were listed in the "frequently used" group, whereas chlorinated phenoxy herbicides and amide pesticides were attributed to the "commonly used" group (Van Hoi et al., 2013). This originated from outbreaks of insects in recent years, especially in 2006 with brown hopper. Half of the used pesticides belonged to the WHO categories of II and III (moderately and slightly hazardous, respectively). Organophosphates and, to a lesser extent, organochlorine pesticides were still applied by the farmers, with their active ingredients falling into category II (Van Hoi et al., 2013). During the past two decades, the frequency of application of organochlorine and organophosphate compounds have decreased gradually while the application of pyrethroid and carbamate insecticides have become more regular (Van Hoi et al., 2013). According to WHO's category of hazardousness, even if some pesticides were banned or restricted in economically developed countries, they were still applied in developing countries including Vietnam, thus creating serious health problems and environmental contamination (Donald, 2001). Vietnamese farmers still use some hazardous pesticides even though they are banned, probably due to the availability of stocks, cheaper price and effectiveness for pests (Dung and Dung, 2003).

Selling pesticides in Vietnam also requires regulation. Although the Government, MARD, and the People's Committee of provinces have issued regulations on the business of pesticides, particularly on substances used on vegetables, the illegal business could be found everywhere. In 2007, a total of 13,664 commercial pesticides stores were checked and there were 2,030 cases of violations, mainly due to inadequate business conditions (857 cases), false labels mark (333 cases), expired products and (302 cases) poor quality products $(\mathrm{Ha}, 2015)$. In addition, the number of stores without licenses for business and professional practice certificates remains high and popular, e.g., 16.5\% in Hanoi and $25.0 \%$ in Thai Binh. Overall, this scenario is alarming for the pesticide marketing practices, and the business management systems require implementing strict regulations.

\section{PESTICIDES ENVIRONMENTAL BURDEN: THE NORTH AND THE SOUTH}

During 1986-1990 the use of such large quantity of pesticides caused a high presence of residues in the environment and associated severe outcomes in both humans and animals. The use of certain pesticides also entrained the pollution by dioxins. In the past, the main source of dioxin in Vietnam has been the Agent Orange (prepared from phenoxy herbicide with small amounts of the highly toxic dioxin congener) and other defoliant herbicides sprayed in southern Vietnam during the Vietnam War (Ngo et al., 2006; Đỗ and Kim, 2009). After 1960, American government had sprayed more than 45 million liters of Agent Orange in 10 years (Minh et al., 2008) and no one made sure that this pollution had broken up completely in the sprayed areas.

From the early 1990s, agriculture of Vietnam has attained advances under intensive cultivation. Both production and yields per crop have increased significantly at the farm level, but on the other hand a corresponding increase in the quantity of pesticides used in the absence of regulation is plausible.

In the Mekong delta (south of Vietnam), pesticides are used much more than in Song Hong (Red river) Delta (north of Vietnam) because the area and rice farming in the south is bigger than in the north (Dung and Dung, 2003). Rice farmers used organophosphate and organochlorine insecticides, but the trend to use pyrethroids has rapidly increased here. It is reported that 64 different active ingredients were used in rice cultivation in Can Tho and Tien Giang Provinces of Vietnam (Van Hoi et al., 2013). People used such hazardous pesticides also for fruit gardens. Even though some types of pesticides were banned according to their toxicity (organochloride and organophosphate compounds), some of them (e.g., methylparathion and endosulfan) have still been used in the Mekong delta (Van Hoi et al., 2013). In the Mekong delta, rice cultivation combined with fish farming in rice paddy fields is popular. According to Berg (2001), pesticides were used much more in the paddy field without fish while they were used less in the paddy field combined with fish culturing due to the effect of pesticides on fish farming.

Difference between the north and the south of Vietnam was also in terms of:

- Expenditures; the expenditures on pesticides of farmers in the Mekong delta (39.3 USD per ha) was remarkable higher than in the Red river delta (22.3 USD per ha);

- Frequency of application; the frequency of application was greater in the Mekong delta (on average, pesticides are applied 5.3 times per crop season) than in the Song Hong Delta (3 times per crop), although very high applications of pesticides could be seen in most rice farming regions of the whole country.

Severe pesticide contamination from various sources has been described. Comprehensive monitoring surveys of Minh et al. (2007) showed that POP contamination of air, water and sediment in Vietnam was rather higher than in developed countries such as Japan. 
According to a survey of Hoai et al. (2010), all sediment samples from sewage rivers system in Hanoi (such as To lich, Kim Nguu, Nhue, Lu, Set, and Yen So lake) were positive with DDT, PCB, hexachlorocyclohexane ( $\mathrm{HCH})$, and $\mathrm{HCB}$. According to Nhan et al. (1998), chlorinated pesticides, PCBs and DDT were detected in sediment samples but also in biota, especially in mollusks living in fresh water canal in Hanoi region with high levels (Nhan et al., 1998). This study also showed that in densely populated areas DDTs were detected at the highest concentration while in rural areas it was detected at lower concentration (Nhan et al., 2001). These findings suggest that the DDT could have been used to control mosquito and other insects in overpopulated areas. Another study in the largest paddy rice showed that water samples were positive to polar compounds e.g., diazinon and fenotrothion, while many samples of sediments and biota were positive to many kinds of non-polar chlorinated compounds like DDT, HCH, endosulfan and PCBs (Hoai et al., 2010). Vietnam is a country with higher level of OC residue than other countries in fish, mussels and birds (Minh et al., 2007; Hoai et al., 2010).

Interestingly, a study on pesticides concentration in wildlife in 1997 revealed that the concentration of DDT in the migratory birds is lower than in the resident ones in Vietnam (Minh et al., 2002). In particular, a relationships exist between places with elevated DDT and rate of exposure to DDT in resident birds from North Vietnam.

According to Minh et al. (2004), pesticide compounds, particularly $\mathrm{HCH}$, were detected in human breast milk in Vietnam, with significant differences between the north (Hanoi) and the south (Ho Chi Minh City). This suggests recent high background levels of $\mathrm{HCH}$, as found in a variety of environmental samples in the Hanoi compared to Ho Chi Minh City (Minh et al., 2004). It may be due to possible import from China, one of the high $\mathrm{HCH}$ users, and differences in climate between Hanoi and Ho Chi Minh City. In fact, the Mekong River delta in the southern Vietnam is characterized by the typical tropical climate with high temperature and heavy rainfall. Rapid volatilization of highly volatile $\mathrm{HCH}$ isomers may therefore be enhanced in the environment of southern Vietnam, resulting in lower residues in various environmental and human samples. Similar to the environmental exposure, human exposure to DDT in Vietnam was very high and ranked among the highest respect to developing countries and developed nations (Donald, 2001; Minh et al., 2004; Carvalho et al., 2008).

Based on the survey carried out in the Anh Son district, Nghe An province, in 2011, the spread of chemicals in soil and groundwater has been described and calculated (Pham, 2011). Pesticide residues have been dispersed into the environment, with serious health effects on generations of animals and humans.

\section{POTENTIAL LONG-TERM HEALTH RISKS OF UNREGULATED USE OF PESTICIDES}

The prevention of NCDs finds one strategic step in the prevention of environmental risk factors for homeostatic imbalances and metabolic disruption (Mostafalou and Abdollahi, 2013; Heindel et al., 2015). Lifestyle factors such as decreased physical activity and energy rich diet, together with a genetic predisposition, are known as main factors in the onset of metabolic dysregulation and metabolic syndrome and related obesity, diabetes, and cardiovascular risks (Kirkley and Sargis, 2014). On the other side, the limited success in reversing such morbidities by focusing solely on nutrition, physical exercise or drug therapies fosters the hypothesis of a significant contribution from environmental chemical factors (Heindel et al., 2015).

Pre- and post-natal metabolic programming is largely dependent on endocrine homeostasis (Le Magueresse-Battistoni et al., 2016; De Long and Holloway, 2017). Endocrine disrupting chemicals (EDCs), including many pesticides, can interfere with the action of hormones including metabolic hormones, and are likely to play a role as risk factors in the onset of metabolic syndrome (Heindel et al., 2015).

According to the Developmental Origins of Health and Disease hypothesis, in utero development is a sequence of "critical/most sensitive windows" in development, during which stressors can alter gene expression, possibly by interacting with the epigenome, protein levels, cell numbers, differentiation and/or arrangement in tissues to make changes in their functions (Heindel and Vom Saal, 2009). In some case, these changes may persist after the stressor is gone (the functional change to be expressed as a phenotype) as well as increase the susceptibility to "second hits" during childhood, adolescence or adulthood, e.g., amount of fat, sugar added in the diet, stress or infection; these developmental hits ultimately lead to increased risk of a variety of NCDs later in life (Heindel et al., 2015; Russ and Howard, 2016). When epigenetic mechanisms are altered, adverse phenotypes may persist until at least the third generation (transgenerational predisposition, from grand-mother to grand-children), thus highlighting the urgent implementation of sustainable food safety policies, i.e., health protection of the generations to come by ensuring the safety of foods today (Frazzoli et al., 2009). There is strong experimental evidence, as well as increasing epidemiological evidence, that prenatal exposures to EDCs (e.g., some groups of plasticizers and pesticides) during development does impact the programming of reproductive as well as neurologic, metabolic, immune functions, and on the maturation of target tissues (Dang et al., 2007). Thus, EDC may affect human development in two ways; they may increase the risk for adverse pregnancy outcomes (e.g., fetal loss, intrauterine growth restriction, preterm birth, birth defects of the genitourinary tract) as well as exert delayed, often long-term, effects including puberty disturbances, infertility and other reproductive disorders, neurobehavioral deficits, increased predisposition to asthma and obesity, and certain adult cancers such as testicular cancers (Latini et al., 2010).

Growing scientific evidence points to infancy, childhood and puberty as potentially sensitive developmental windows for adverse long-term effects on brain, skeletal, metabolic functions, immune system (Dietert, 2014), and for cancer predisposition (Maranghi and Mantovani, 2012). It should also considered how age imparts a growing body burden of bio-accumulating EDCs (Frazzoli et al., 2009), which may worsen the risk and/or the severity of adult health disorders or diseases, such as metabolic syndrome and related cardiovascular disease, diabetes, and 
cancers. Indeed, menopause and aging might represent further windows of enhanced susceptibility to acute, or chronic exposure to metabolic disruptors; however, further research is required to characterize the hazards.

While EDCs are likely to represent the main concern for developmentally-induced NCDs, attention should be given to other chemicals and toxicological targets as well. Oxidative stress, mitochondrial dysfunction, interactions with nutrients (vitamins, essential elements) leading to lipid/glucose dysmetabolism and epigenetic changes in target tissues are events related to an increased risk of metabolic syndrome and/or related diseases (e.g., type 2 diabetes) and/or related pathogenic pathways (e.g., chronic inflammation in the adipose tissue) (Mostafalou and Abdollahi, 2013; Lei et al., 2014). Many pollutants do impinge in such events and pathways, including many toxic elements (e.g., inorganic arsenic, cadmium) and pesticide groups (from glyphosate to paraquat to chlorpiriphos, etc.). The association of type 2 diabetes with exposure to inorganic arsenic (Sung et al., 2015), which is an important pollutant of water bodies and rice as well as an enhancer of oxidative stress and epigenetic alterations, represents a relevant example.

\section{INTEGRATED PEST MANAGEMENT}

Vietnam has adopted an "Integrated Pest Management" (IPM) in rice as a method for protecting plant which has helped, and is helping, increasing the agricultural productivity (Dung and Dung, 2003). It integrates practices for economic control of pests based on a large scale approach. With the aim of suppressing pest populations under the economic injury level (EIL), IPM was defined as "the careful consideration of all available pest control techniques and subsequent integration of appropriate measures that discourage the development of pest populations and keep pesticides and other interventions to levels that are economically justified and reduce or minimize risks to human health and the environment. IPM emphasizes the growth of a healthy crop with the least possible disruption to agroecosystems and encourages natural pest control mechanisms" by the UN's Food and Agriculture Organization (FAO) (FAO, 2011). In March 1989 Vietnam became a participant in the FAO; from that time IPM system was started but only after 1992 Vietnam officially took a part in such network. In 1994, rice farmers were provided with a more efficient service after the setting up of the rice IPM program (Dung and Dung, 2003). Coordinated by the International Rice Research Institute, IPM network transferred knowledge directly to farmers, and helped farmers in increasing their ability in pest management and raise yield and production of rice (Van Mede et al., 2001).

The IPM program in Vietnam run into two direction: (a) training of trainers and (b) field schools. According to the survey reported by Dung and Dung (2003), more than 1350 IPM trainers have undergone training. After this training, the network of 7,000 "farmers' field schools" were covered in more than 50 provinces, with a total of 3,000 villages involved. The members of IPM popularized IPM to other farmers and by this way the farmers participating in the IPM program lessened the usage of pesticides by nearly 75\% (Plant Protection Division, 1996; Dung and Dung, 2003). The IPM farmers got output better than non-IPM farmers according to the less use of fertilizers, seeds and also pesticides. According to Berg, the amount of pesticides used by IPM farmers was half as compared to non IPM farmers. Moreover, IPM farmer also minimized the frequency of pesticides applications from 2 to 3 times per crop (Berg, 2001).

In 2002, Berg showed that the agricultural practice and pest management strategies are not the same between different farmer categories in Mekong Delta. Based on economic comparisons, the results showed that there was a significant difference about net income between IPM rice fish farmers and non IPM ones due to the different production approach (Berg, 2002). The reduction of pesticides use gave the farmers higher incomes ( $\$ 58$ per hectare in the winter-spring, and $\$ 35$ per hectare in other crop) and, in particular, the reduction of used pesticides made $80 \%$ of the increased incomes (Huan et al., 2005).

According to Huan et al. (1999) there are two ways to abate residues of pesticide used in agricultural areas, including media campaigns and farmer field schools. Other approaches than farmer field schools, such as IPM seminars, radio, television or games aimed at educating on plant protection were evaluated as less effective to transfer this technology to farmers. Hence, it was the basic for launching a media campaign to scale up the adoption of these IPM practices at national level.

\section{HINTS FOR RISK ANALYSIS BASED ON ONE HEALTH}

Endocrine disrupting pesticides are directly employed in food production (Mantovani and Frazzoli, 2017). As already mentioned, subjects generally more exposed to risks due to pesticides are agricultural communities: the multifaceted governance scenario starts from risk perception by the users (in their workplace and home) and good pesticide application practices. Empowerment of food producers (at both back yard and commercial production levels) and reducing risks posed by unsafe use of pesticides, are absolutely necessary for minimizing direct and indirect exposure.

Improved risk perception can be obtained for instance through easy, understandable toxicological charts to explain to agriculturists and agronomists the health risks, in both the short and long term, of different pesticides or pesticide groups. The toxicological information can support the agronomists in the formulation of treatment protocols that minimize risks and optimize benefits. Good practices mitigating the contamination of foods of animal origin (meat/milk chains) should cover feed, water, and involuntary soil ingestion as ways of livestock exposure. Integrated rice-fish farming with IPM practices provides an example of feasible implementation of sustainable food productions.

Proper information and communication should be extended to the population for correct use of pesticides in domestic environment. Besides prevention measures, such as cultural controls, biological controls, and appropriate pesticide use, the 
following strategies should be applied to mitigate the residues of pesticides used in agriculture (Van Hoi et al., 2013):

i) While heavy rainfall events are forecasted, pesticides should not be applied. It has been observed how the concentration of pesticides' residues in water is raised when a heavy rain occurs immediately afterpesticides application;

ii) To reduce the transport of pesticides' residues into aquatic environments, water should not be drained soon after pesticide application;

iii) The construction of wetland systems with various combinations of vegetation, sand and gravel should be considered to reduce pesticides in surface water;

iv) To avoid the pollution of surrounding environments from industrial waste discharges, variety of control measures need implementation. All source of industrial waste need to be treated before spilling into water environment based on the lesson learned from Vietnam marine life disaster in 2016, when a steel plant caused mass fish deaths (Nhat, 2017).

The acknowledgement of the effectiveness of "food chain" approach to protect health makes the "from farm to fork" model seeking for governance strategies in Vietnam, starting from the environmental burden and the environments at the food producing animals-humans and plant-humans interfaces. Pesticides are often persistent and bio-accumulate in the food chain through the living environment (e.g., pastures, feeds, fertilizers) of food-producing organisms (Mantovani, 2016). Control strategies, from analytical know how and facilities, monitoring and surveillance tools and plans, laws and regulations (for both pesticides products and residues in foods) are pivotal for health and trade.

Rapid and on-site detection methods are crucial to assess and monitor the environmental burden of pesticide residues. The analytical data should be collected, integrated and assessed using the following categories: (1) hazard identification, (2) dose-response assessment, (3) exposure assessment and (4) risk characterization.

The availability of the data throughout the country should be improved, and biomonitoring of sentinel species (Frazzoli et al., 2014) as well as registers of human and animal health (including malformations) should be foreseen by modernized prevention plans (Frazzoli et al., 2015). Registration system as optimal source of data is currently only seldom fully functional in Vietnam. Among foods, milk has specific vulnerability to contamination with specific EDCs (e.g., polychlorinated and polybrominated chemicals) and is a useful sentinel matrix: indeed, primary milk producers could gain an increasing role in the surveillance of the territory (Mantovani, 2016).

New technologies and methodologies accounting for the potential for "cocktail" effects from multiple pesticide residues will support the "mixtures approach." Indeed, multiple chemicals with different half- lives, metabolism, persistence, tissue accumulation and target sensitivities affect many aspects of metabolism (Kirkley and Sargis, 2014). Metabolic disruption is crucial to the effectiveness of prevention plans (cumulative exposure). Environmental chemical factors disturb cellular homeostasis and cause homeostatic imbalances, thus posing as a risk factor affecting the ability of the body to restore a functional internal environment.

Finally, all substances that induce a similar effect in the same organ/tissue (e.g., reduced thyroid function) should be considered in the assessment of cumulative risk, regardless of any differences in chemical structures and/or toxicity mechanisms at biochemical/molecular level. The most accurate and protective model to describe a cumulative effect is additive: indeed, substances can contribute in a summative way to the same effect, each with their potency estimated from the available toxicological data.

\section{CONCLUSIONS}

Non-communicable diseases are increasing in Vietnam also due to environmental chemical risk factors as a result of poor or ineffective management of pesticides market and use.

The design of appropriate prevention and control measures requires one health and sustainable food safety plans protecting developmental phases of (as mentioned) two generations.

The United Nations Development Program (UNDP) project on the support of capacity, coordination and knowledge sharing for the application of one health approach, has been recently (2011-2015) approved by the government of Vietnam. Lessons learned from one health interventions in biological outbreaks in Vietnam as well as current knowledge of environmental fate of pesticides make the building of one health governance mechanism strategic and feasible. The contribution of all actors, from associations of farmers, consumers, plant protection departments, control agencies/bodies, ministries, media sectors (e.g., pesticides producers, government bodies, regulatory authorities) and disciplines (e.g., environmental health, agronomy, veterinary sciences, public health) dealing with human and animal health, foods and the environment are called to protect and improve health, with positive outputs for the general public, agro-farming productions, domestic, synanthropic and wild animal populations, based on the sharing of living resources and reciprocal interconnections. Good governance mechanisms (including sustainable food safety system) can contribute to the formulation of the national strategic plan and policy for NCDs in Vietnam. These would also safeguard the chances of a healthy adulthood for fetuses and children by preventing the toxic body burden of women in childbearing age. Indeed, to pursue sustainable development in Vietnam, new governance schemes should include toxicants that are able to interfere with developing organisms, as well as the alleviation of the environmental burden of pesticides.

\section{AUTHOR CONTRIBUTIONS}

HD wrote and revised the final version. LN wrote and revised the manuscript. HT, HN, AD and VL collected articles and references. CF gave the concept of manuscript, revised the manuscript. 


\section{ACKNOWLEDGMENTS}

The paper was written with support from the Ministry of Agriculture and Rural Development (MARD), Vietnam, and in the frame of the ALERT project (www.alert2015.org) funded by the Italian Ministry of Economic Development. The bottom-up initiatives for clean food productions of the

\section{REFERENCES}

Berg, H. (2001). Pesticide use in rice and rice-fish farms in the Mekong Delta, Vietnam. Crop Prot. 20, 897-905. doi: 10.1016/S0261-2194(01)00039-4

Berg, H. (2002). Rice monoculture and integrated rice-fish farming in the Mekong Delta, Vietnam- economic and ecological considerations. Ecol. Econ. 41, 95-107. doi: 10.1016/S0921-8009(02)00027-7

Carvalho, F. P., Villeneuve, J. P., Cattini, C., Tolosa, I., Thuan, D. D., and Nhan, D. D. (2008). Agrochemical and polychlorobyphenyl (PCB) residues in the Mekong River delta, Vietnam. Mar. Pollut. Bull. 56, 1476-1485. doi: 10.1016/j.marpolbul.2008.04.042

Chevalier, N., and Fénichel, P. (2014). Endocrine disruptors: a missing link in the pandemy of type 2 diabetes and obesity? Curr. Opin. Pharmacol. 19, 120-124. doi: 10.1016/j.lpm.2015.08.008

Costa, L. G., Giordano, G., Guixxetti, M., and Vitalone, A. (2008). Neurotoxicity of pesticides: a brief review. Front. Biosci. 13:2758. doi: 10.2741/2758

Dang, V. H., Nguyen, T. H., Choi, K. C., and Jeung, E. B. (2007). Unexpected estrogenicity of endocrine disruptors may evoke a failure of pregnancy derived from uterine function: overview of their possible mechanism(s) through steroid receptors. J. Emb. Trans. 22, 199-208. Available online at: http://ksci. kisti.re.kr/search/article/articleView.ksci?articleBean.atclMgntNo=SJROBD_ 2007_v22n4_199

De Long, N. E., and Holloway, A. C. (2017). Early-life chemical exposures and risk of metabolic syndrome. Diabetes Metab. Syndr. Obes. 10, 101-109. doi: 10.2147/DMSO.S95296

Dietert, R. R. (2014). Developmental immunotoxicity, perinatal programming, and noncommunicable diseases: focus on human studies. Adv. Med. 2014:867805. doi: $10.1155 / 2014 / 867805$

Đỗ, K. C., Kim, T. D. (2009). Nhân thức úng xủ của người dân trồng rau ở Thái Bình và Hà Nội về rủi ro thuốc bảo vệ thực vật. Nhà xuất bản Chính trị Quốc gia Hà Nội.Đỗ Kim Chung, Kim Thi Dung (2009). Nhận thức và ứng xử của người dân trồng rau ở Thái Bình và Hà Nội về rủi ro thuốc bảo vệ thực vật, trang 141-162, Trích từ sách "Hạn chế lạm dụng thuốc trừ sâu vì sức khỏe phụ nữ và một nền nông nghiệp sạch”, NXB Chính trị quốc gia, Hà Nội.

Donald, J., E. (2001). Pesticide use in developing countries. Toxicology 160, 27-33. doi: $10.1016 /$ S0300-483X(00)00452-2

Dung, N. H., and Dung, T. T. (2003). Economic and Health Consequences of Pesticide Use in Paddy Production in the Mekong Delta. Vietnam. Available online at: http://203.116.43.77/publications/research1/ACF124.html

European Food Safety Authority (2014). Panel on plant protection products and their residues. Scientific opinion on the identification of pesticides to be included in cumulative assessment groups on the basis of their toxicological profile (2014 update). EFSA J. 11:3293. doi: 10.2903/j.efsa.2013.3293

European Food Safety Authority (2016). Panel on plant protection products and their residues $(p p r)$, scientific opinion on the investigation into experimental toxicological properties of plant protection products having a potential link to parkinson's disease and childhood leukaemia. Draft Public Consult. 5:4691. doi: 10.2903/j.efsa.2017.4691

FAO (2011). Integrated Pest Management. Available online at: http://www.fao.org/ agriculture/crops/core-themes/theme/pests/ipm/en/ (Accessed 22 February 2011).

Frazzoli, C., and Mantovani, A. (2010). Toxicants exposures as novel zoonoses: reflections on sustainable development, food safety and veterinary public health. Zoonoses Public Health 57, e136-e142. doi: $10.1111 /$ j.1863-2378.2009.01309.x
North-South and South-South Network NOODLES (Nutrition \& food safety and wholesomeness. Prevention, education and research Network, www.noodlesonlus.org) are also acknowledged. Authors would like to acknowledge Drs. Rukhsana Lalani and Aftab Ahmed from Chapman University School of Pharmacy, Irvine, California, USA for their kindly supports of English revision.
Frazzoli, C., Bocca, B., and Mantovani, A. (2015). The one health perspective in trace elements biomonitoring. J. Toxicol. Environ. Health 18, 344-370. doi: 10.1080/10937404.2015.1085473

Frazzoli, C., Mantovani, A., and Dragone, R. (2014). Local role of food producers' communities for a Global One-Health framework: the experience of translational research in an Italian dairy chain. J. Agr. Chem. Environ. 3, 14-19. doi: 10.4236/jacen.2014.32B003

Frazzoli, C., Orisakwe, O. E., Dragone, R., and Mantovani, A. (2010). Diagnostic health risk assessment of e-waste on the general population in developing countries' scenarios. Environ. Impact Assess. Rev. 30, 388-399. doi: 10.1016/j.eiar.2009.12.004

Frazzoli, C., Petrini, C., and Mantovani, A. (2009). Sustainable development and next generation's health: a long-term perspective about the consequences of today's activities for food safety. Ann. dell'Istitut. Super. di Sanità 45, 65-75.

Fucic, A., and Mantovani, A. (2014). Puberty dysregulation and increased risk of disease in adult life: possible modes of action. Reprod. Toxicol. 44, 15-22. doi: 10.1016/j.reprotox.2013.06.002

Ha, T. (2015). Vietnam Spends $\$ 463$ Million on Imported Pesticides. Vietnamnet.vn. Vietnam.net. Available online at: http://english.vietnamnet.vn/fms/business/ 137254/vietnam-spends- - 137463-million-on-imported-pesticides.html

Heindel, J. J., and Vom Saal, F. S. (2009). Role of nutrition and environmental endocrine disrupting chemicals during the perinatal period on the aetiology of obesity. Mol. Cell Endocrinol. 304, 90-96. doi: 10.1016/j.mce.2009.02.025

Heindel, J. J., vom, F. S., Blumberg, B., Bovolin, P., Calamandrei, G., Ceresini, G., et al. (2015). Parma consensus statement on metabolic disruptor. Environ. Health 2015, 14-54. doi: 10.1186/s12940-015-0042-7

Hoa, N. P., Chalapati, R., Damian, G., Hoy, N., and Duc, N. T. (2012). Mortality measures from sample-based surveillance: evidence of the epidemiological transition in Vietnam. Bull. World Health Org. 90, 764-772. doi: 10.2471/BLT.11.100750

Hoai, P. M., Ngoc, N. T., Minh, N. H., Viet, P. H., Berg, M., Alder, A. C., et al. (2010). Recent levels of organochlorine pesticides and polychlorinated biphenyls in sediments of the sewer system in Hanoi, Vietnam. Environ. Pollut. 158, 913-920. doi: 10.1016/j.envpol.2009.09.018

Hong, N, X. (2015). Head of Plant Protection Department Vietnam nhập khẩu 100 ngàn tấn thuốc bảo vệ thực vật mỗi năm. Phúc Nguyên phỏng vấn. Available online at: http://thoibaotaichinhvietnam.vn/pages/kinh-doanh/2015-06-17/ viet-nam-nhap-khau-100-nghin-tan-thuoc-bao-ve-thuc-vat-moi-nam21835.aspx.

Hop, L. T., Van, T. K., and Thanh, H. K. (2011). Food based dietary guidelines in Vietnam: progress and lessons learned. Asia Pac. J. Clin. Nutr. 20, 495-499. Available online at: http://apjcn.nhri.org.tw/server/APJCN/20/3/495.pdf

Huan, N. H., Mai, V. M., and Escalada, K. L. (1999). Changes in rice farmers pest management in the Mekong Delta, Vietnam. Crop Prot. 18, 557-563. doi: 10.1016/S0261-2194(99)00059-9

Huan, N. H., Thiet, L. V., Chien, H. V., and Heong, K. L. (2005). Farmers' participatory evaluation of reducing pesticides, fertilizers and seed rates in rice farming in the Mekong Delta, Vietnam. Crop Protect. 24, 457-464. doi: 10.1016/j.cropro.2004.09.013

Huong, D. L. (2006). Mortality in Transitional Vietnam. Umeå University Medical Dissertations. Umeå, Sweden: Umeå University, SE-901 87.

Hussein, S. A. (2011). "Environment and health of rural women," in Encyclopedia of Environmental Health, ed J. O. Nriagu (Burlington, VT: Elsevier), 551-558.

Jaacks, L. M., and Staimez, L. R. (2015). Association of persistent organic pollutants and non-persistent pesticides with diabetes and diabetes-related 
health outcomes in Asia: a systematic review. Environ. Int. 76, 57-70. doi: 10.1016/j.envint.2014.12.001

Khalil, N., Chen, A., and Lee, M. (2015). Endocrine disruptive compounds and cardio-metabolic risk factors in children. J. Clin. Endocrinol. Metab. 100, 1792-1801. doi: 10.1016/j.coph.2014.09.015

Kirkley, A. G., and Sargis, R. M. (2014). Environmental endocrine disruption of energy metabolism and cardiovascular risk. Curr. Diab. Rep. 14:494. doi: 10.1007/s11892-014-0494-0

Latini, G., Knipp, G., Mantovani, A., Marcovecchio, M. L., and Chiarelli, F., Soder, O. (2010). Endocrine disruptors and human health. Mini. Rev. Med. Chem. 10, 846-855. doi: 10.2174/138955710791608271

Le Magueresse-Battistoni, B., Vidal, H., and Naville, D. (2016). Impact of in utero exposure to pollutants on metabolic health in adults. Med. Sci. 32, 51-56. doi: $10.1051 /$ medsci/20163201009

Lei, S., Zavala-Flores, L., Garcia-Garcia, A., Nandakumar, R., Huang, Y., Madayiputhiya, N., et al. (2014). Alterations in energy/redox metabolism induced by mitochondrial and environmental toxins: a specific role for glucose6-phosphate-dehydrogenase and the pentose phosphate pathway in paraquat toxicity. ACS Chem. Biol. 9, 2032-2048. doi: 10.1021/cb400894a

Mantovani, A. (2016). Endocrine disrupters and the safety of food chains. Horm. Res. Paediatr. 86, 279-288. doi: 10.1159/000441496

Mantovani, A., and Frazzoli, C. (2017). Endocrine Disrupting Chemicals: from Feeds to Hormones, Adjacent government, U. K. profile, May 2017.

Mantovani, A., Ferrari, D., and Frazzoli, C. (2015). Sustainability, security and safety in the feed-to-fish chain: focus on toxic contamination. Int. J. Nut. Food Sci. 4, 6-24. doi: 10.11648/j.ijnfs.s.2015040202.12

Maranghi, F., and Mantovani, A. (2012). Targeted toxicological testing to investigate the role of endocrine disrupters in puberty disorders. Reprod. Toxicol. 33, 290-296. doi: 10.1016/j.reprotox.2012.01.009

Minh, N. H., Someya, M., Minh, T. B., Kunisue, T., Watanabe, M., Takahashi, S., et al. (2004). Persistent organochlorine residues in human breast milk from Hanoi and Ho Chi Minh City, Vietnam: contamination, accumulation Kinetics and risk assessment for infants. Environ. Pollut. 129, 431-441. doi: 10.1016/j.envpol.2003.11.012

Minh, T. B., Iwata, H., Takahashi, S., Viet, P. H., Tuyen, B. C., and Tanabe, S. (2008). Persistent organic pollutants in Vietnam: environmental contamination and human exposure. Rev. Environ. Contam. Toxicol. 193, 213-290. doi: 10.1007/978-0-387-73163-6_4

Minh, T. B., Kunisue, T., Yen, N. T. H., Watanabe, M., Tanabe, S., Hue, N. D., et al. (2002). Persistent organochlorine residues and their bioaccumulation profiles in resident and migratory birds from North Vietnam. Environ. Toxicol. Chem. 21, 2108-2118. doi: 10.1002/etc.5620211014

Minh, T. B., Minh, N. H., Iwata, H., Takahashi, S., Viet, P. H., Tuyen, B. C., et al. (2007). Persistent organic pollutants in Vietnam: levels, patterns, trends, and human health implications. Dev. Environ. Sci. 7, 515-555. doi: 10.1016/S1474-8177(07)07011-8

Mostafalou, S., and Abdollahi, M. (2013). Pesticides and human chronic diseases: evidences, mechanisms, and perspectives. Toxicol. Appl. Pharmacol. 268, 157-177. doi: 10.1016/j.taap.2013.01.025

Ngo, A. D., Taylor, R., Roberts, C. L., and Nguyen, T. V. (2006). Association between agent orange and birth defects: systematic review and meta analysis. Int. J. Epidemiol. 35, 1220-1230. doi: 10.1093/ije/dyl038

Nhan, D. D., Carvalho, F. P., Am, N. M., Tuan, N. Q., Yen, N. T. H., Villeneuve, J. P., et al. (2001). Chlorinated pesticides and PCBs in sediments and molluscs from freshwater canals in the Hanoi region. Environ. Pollut. 112, 311-320. doi: 10.1016/S0269-7491(00)00149-4

Nhan, D. D., Nguyen, M. A., Nguyen, C, H., Luu, V., Carvalho, F. P., Cattini, C., et al. (1998). Organochlorine pesticides and PCBs in the Red River Delta, North Vietnam. Mar. Pollut. Bull. 36, 742-749. doi: 10.1016/S0025-326X(98)00025-3

Nhat, L. (2017). Panoramic view of mass fish death in Central Vietnam. J. Vietnam. Ministry Inform. Commun. Vietnam.
Pham, V. T. (2011). Pesticide Use and Management in the Mekong Delta and their Residues in Surface and Drinking Water. Institute for Environment and Human Security, United Nations University in Bonn.

Plant Protection Division (1996). National IPM Programme. Hanoi: Plant Protection Division.

Russ, K., and Howard, S. (2016). Developmental exposure to environmental chemicals and metabolic changes in children. Curr. Probl. Pediatr. Adolesc. Health Care 46, 255-285. doi: 10.1016/j.cppeds.2016.06.001

Sarter, S., Ho Phu, H. A., and To Kim, A. (2012). "Current situation of food safety in Vietnam," in 1st FOODSEG Symposium (Berlin), 21-22. Available online at: http://agritrop.cirad.fr/566838/1/document_566838.pdf.

Sung, T.-C., Huang, J.-W., and Guo, H.-R. (2015). Association between arsenic exposure and diabetes: a meta-analysis. BioMed. Res. Int. 2015, 1-10. doi: $10.1155 / 2015 / 368087$

Thuong Hien, P. T. (2014). Đánh giá tình hình sản xuất và xuất khẩu lúa gạo của Việt Nam tù̀ thập niên 1990 trở lại đây. Trang: Chuyên san Kinh tế đối ngoại -kỳ 11-2014.

Toan, P. V., Sebesvari, Z., Bläsing, M., Rosendahl, I., and Renaud, F. G. (2013). Pesticide management and their residues in sediments and surface and drinking water in the Mekong Delta, Vietnam. Sci. Tot. Environ. 452-453, 28-39. doi: 10.1016/j.scitotenv.2013.02.026

Tomar, L. R., Agarwal, M. P., Avasthi, R., Tyagi, V., Mustafa, M., and BD, B. (2013). Serum organochlorine pesticide levels in patients with metabolic syndrome. Indian J. Endocrinol. Metab. 17, S342-S344. doi: 10.4103/2230-8210.119612

Van Der Mark, M., Brouwer, M., Kromhout, H., Nijssen, P., Huss, A., and Vermeulen, R. (2012). Is pesticide use related to Parkinson disease? Some clues to heterogeneity in study results. Environ. Health Perspect. 120, 340-347. doi: 10.1289/ehp.1103881

Van Hoi, P., Mol, A. P. J., and Oosterveer, P. J. M. (2009). Market governance for safe food in developing countries: the case of low-pesticide vegetables in Vietnam. J. Environ. Manage. 91, 380-388. doi: 10.1016/j.jenvman.2009.09.008

Van Hoi, P., Mol, A., and Oosterveer, P. (2013). State governance of pesticide use and trade in Vietnam. J. Life Sci. 67, 19-26. doi: 10.1016/j.njas.2013.09.001

Van Mede, P., Cuc, N. T. T., and Van Huis, A. (2001). Farmers' knowledge, perceptions and practices in mango pest management in the Mekong Delta, Vietnam. Int. J. Pest Manage. 47, 7-16. doi: 10.1080/096708701502 15559

Wenjun, Z., Fubin, J., and JiangFeng, O. (2011). Global pesticide consumption and pollution: with China as a focus. Int. Acad. Ecol. Environ. Sci. 1, 125-144. Available online at: http://agris.fao.org/agris-search/search.do? recordID $=$ CN2011200030

World Health Organization (2012). Representative Office in Vietnam Country profile 2012; Non-Communicable Diseases. Hanoi: WHO.

World Health Organization (2014). Noncommunicable Diseases (NCD) Country Profiles. Available online at http://www.who.int/nmh/countries/vnm_en.pdf

Conflict of Interest Statement: The authors declare that there is no conflict of interest. I am representative for all authors declare that this is the only time that our article submission.

The reviewers MS, MA and handling Editor declared their shared affiliation, and the handling Editor states that the process nevertheless met the standards of a fair and objective review.

Copyright (c) 2017 Dang, Nguyen, Tran, Nguyen, Dang, Ly and Frazzoli. This is an open-access article distributed under the terms of the Creative Commons Attribution License (CC BY). The use, distribution or reproduction in other forums is permitted, provided the original author(s) or licensor are credited and that the original publication in this journal is cited, in accordance with accepted academic practice. No use, distribution or reproduction is permitted which does not comply with these terms. 